\title{
Reactions of Sweet Corn Hybrids with Resistance to Maize Dwarf Mosaic
}

\author{
M. R. Kerns and J. K. Pataky, Department of Crop Sciences, University of Illinois, Urbana 61801
}

\begin{abstract}
Kerns, M. R., and Pataky, J. K. 1997. Reactions of sweet corn hybrids with resistance to maize dwarf mosaic. Plant Dis. 81:460-464.

Maize dwarf mosaic (MDM), caused by the sugarcane mosaic subgroup of potyviruses, can substantially reduce yield and ear quality of sweet corn (Zea mays). The effects of strain A of maize dwarf mosaic virus (MDMV-A) and strain MDMV-B of sugarcane mosaic virus (SCMV-MB) on resistant sweet corn hybrids were evaluated. Incidence of symptomatic plants, types of symptomatic responses, yield, and ear quality were compared among 20 hybrids in 1993 and 14 hybrids in 1994. Incidence of symptomatic plants measured at the beginning of harvest ranged from 4 to $100 \%$ in 1993 and 1 to $100 \%$ in 1994 and differed among hybrids inoculated with MDMV-A and/or SCMV-MB. Hybrids BiGuard, Dallas, HMX 9352, and Topacio had low $(<20 \%)$ incidences of symptomatic plants when inoculated with MDMV-A, SCMV-B, or MDMV-A/SCMV-MB. Some hybrids had moderate responses, with incidence varying around $25 \%$. Some hybrids appeared to have greater resistance to MDMV-A than to SCMV-MB. The incidence of sectoring plants (i.e., distinct bands or sectors of asymptomatic and symptomatic tissue) was higher for hybrids with high levels of resistance and ranged from 0 to $14 \%$ in 1993 and 0 to $83 \%$ in 1994. Ear weight of inoculated hybrids, expressed as a percentage of the noninoculated control, ranged from 84 to $109 \%$ in 1993 and from 84 to $105 \%$ in 1994. Slope coefficients from regressions of percent ear weight on incidence ranged from -0.085 to -0.15 . Butt blanking was associated with high incidence of MDM-symptomatic plants. None of the commercially available MDM-resistant sweet corn hybrids were $100 \%$ asymptomatic, but levels of resistance in most of these hybrids were adequate to minimize the effects of MDM on yield.
\end{abstract}

Yield and ear quality of sweet corn (Zea mays L.) can be reduced by maize dwarf mosaic (MDM). When Janson and Ellett (6) first reported the disease from southern Ohio, they observed nearly total losses in fields of late-planted sweet corn.

Yield reduction due to MDM and symptom expression are affected by the growth stage at which sweet corn is infected $(5,12$, $18,25)$. When late plantings of sweet corn are exposed to large populations of viruliferous aphids, plants can be infected at early stages of host growth. Infection at juvenile growth stages reduces plant height, delays maturity, decreases ear diameter and length, reduces ear weight, and increases the number of missing kernels in the basal end of the ear, which is commonly called butt blanking $(5,17,18)$. Butt blanking results from retarded growth of pollen germ tubes on silks of infected plants (19), and it reduces the marketability of sweet corn used for fresh market and the weight of kernels cut from the cob that are used for processing.

Yields of susceptible sweet corn hybrids can be reduced as much as $40 \%$ by MDM

Corresponding author: J. K. Pataky

E-mail: j-pataky@uiuc.edu

Portion of a thesis submitted by M. R. Kerns in partial fulfillment of the M.S. degree.

Accepted for publication 30 January 1997.

Publication no. D-1997-0310-05R

(C) 1997 The American Phytopathological Society
$(5,17,18,21)$. Reductions of up to $12 \%$ were observed when two sweet corn hybrids were inoculated at various growth stages with maize dwarf mosaic virus (MDMV-A) (5). Yield was reduced as much as $36 \%$ when hybrids were inoculated with sugarcane mosaic virus (SCMV-MB) at the four- to fiveleaf stage (17). Reductions of $15 \%$ occurred when hybrids were inoculated at various growth stages with a mixture of MDMV-A and SCMV-MB (17). Yield reductions were as large as $40 \%$ when hybrids were inoculated at the three- to fourleaf stage with MDMV-A or SCMV-MB/ MDMV-A (21).

Planting MDM-resistant hybrids is the most feasible method of controlling MDM, because control of aphid vectors is not practical. Resistance to MDM is thought to be expressed through restriction of cell-tocell movement of the virus $(11,12,15)$, interference with systemic movement (14), lower concentrations of virus $(1,7,10,15$, 21 ), and hypersensitive reactions that localize viral infection to a few cells (15). Hybrids and inbreds with genes for resistance to MDM do not always exhibit asymptomatic responses after infection $(7,12,21$, 25). Scott and Rosenkranz (25) suggested that symptomatic reactions may be induced by microenvironmental influences, expression of resistance at late growth stages, inoculum concentrations above a specific threshold, or a combination of these factors. Jones and Tolin (7) observed an unusual reaction in resistant hybrids expressed as distinct sectors of symptomatic and asymp- tomatic tissue. Concentration of virus was high in chlorotic, symptomatic sectors, but virus was not detected in asymptomatic sectors (7). Sectoring may be the result of restricted cell-to-cell movement of a virus due to a mechanism of resistance $(7,12)$.

Sources of resistance to MDM in sweet corn have not been identified or widely used, although some sugary enhancer inbreds may express partial resistance (2). Genes for resistance from dent corn sources, such as Pa405, Ga209, and B68, have been introgressed into commercial and public sweet corn inbreds $(1,8,16)$. The inheritance of resistance to MDM may be controlled by one or more genes, possibly involving modifiers or minor genes $(3,4,9,13,14,20,22$, 24). A single dominant gene, $M d m 1$, on the short arm of chromosome 6 appears to be involved in resistance to all viral strains causing MDM (15). Louie et al. (14) postulated a common genetic basis of resistance to all strains; however, Scheifele and Wernham (24) observed different genetic systems controlling reactions to MDMV-A and SCMV-MB. Modifier genes may be associated with specific resistance to MDMV-A and SCMV-MB (14) and with the degree of cell-to-cell movement of virus that can result in sectoring symptoms and systemically symptomatic plants in spite of some resistance genes.

Most of the previous research on the effects of MDM on yield evaluated the reactions of susceptible hybrids to MDMV-A or SCMV-MB $(5,17,18,21)$. Although previous studies have demonstrated that MDM reduces yield, it is not apparent that yields of resistant hybrids with varying incidences of symptomatic reactions will be entirely unaffected by infection. The objectives of this study were to compare the incidence of MDM infection and types of symptomatic responses among commercial sweet corn hybrids with resistance to MDM and to determine the effects of MDMV-A and SCMV$\mathrm{MB}$ on the yields of these hybrids.

\section{MATERIAL AND METHODS}

Field experiments were done at the Agronomy/Plant Pathology South Farm, Champaign, IL, in 1993 and 1994. The experimental design was a split plot with main plots arranged in a randomized complete block, with two or three replications in 1993 and five replications in 1994. Hybrids were planted in main plots, and viral treatments were applied to subplots. Experimental units were four-row plots with 15 plants per row. Rows were spaced $76 \mathrm{~cm}$ apart and were $4.7 \mathrm{~m}$ long. Seed was planted on 22 and 23 May 1993 and 19 May 1994. 
The treatment design was a factorial of hybrids and four inoculation treatments: MDMV-A, SCMV-MB, MDMV-A/SCMV$\mathrm{MB}$, and a noninoculated control. Twenty hybrids were evaluated in 1993 . Fourteen hybrids were planted in three replicates, and six were planted in two replicates. Eighteen hybrids were planted in five replicates in 1994. Twelve hybrids were common to both trials. Commercial and experimental hybrids with MDM resistance contributed by one or both inbred parents were evaluated, as were susceptible commercial hybrids that served as checks. One hybrid, Sundance, thought to be tolerant to MDM also was included.

MDMV-A and SCMV-MB were obtained from and confirmed by R. E. Ford (University of Illinois, Urbana) and R. Louie (The Ohio State University, Wooster) and maintained in separate greenhouses on susceptible sweet corn. To increase inoculum, a mixture of MDM-susceptible sweet corn hybrids was inoculated in isolated field plots during early May. Plants inoculated with MDMV-A or SCMV-MB for the purpose of increasing inoculum were separated in the field by at least $30 \mathrm{~m}$, and aphid vectors were not observed visually during May.

Inoculum was prepared by harvesting leaves from field-grown, symptomatic plants that had been mechanically inoculated with MDMV-A or SCMV-MB 14 to 21 days previously. Leaves were added to $0.1 \mathrm{M}$ potassium phosphate buffer (approximately $1 \mathrm{~g}$ of tissue per $4 \mathrm{ml}$ of buffer) $(\mathrm{pH} \mathrm{7})$ and blended in a Waring blender for $1 \mathrm{~min}$. The homogenate was filtered through cheesecloth. MDMV-A and SCMV-MB were kept separate at all times during preparation, and separate equipment was used to avoid cross-contamination. Carborundum was added to the inocula at about $5 \mathrm{~g} / \mathrm{liter}$. The underside of the youngest, fully expanded leaf of each plant was inoculated mechanically with a painter's airbrush operated at $5.6 \mathrm{~kg} / \mathrm{cm}^{2}$ on 9,17 , and 24 June 1993 and 13 and 17 June 1994. Plants were at the two- to three-leaf stage when first inoculated.

Stand counts and incidence of symptomatic plants in the middle two rows of the four-row plots were recorded on 22 June 1993 and 1 July 1994. Incidence also was measured on 2 July 1993. Incidence of systemically symptomatic plants and incidence of sectoring plants (plants with discrete bands of symptomatic and asymptomatic tissue usually following the veins of leaves) were recorded 2 to 4 days prior to the beginning of harvest on 28 July 1993 and 21 July 1994.

Ears were harvested about 21 days after the midsilk growth stage. Due to maturity differences among hybrids, harvest dates ranged from 30 July to 10 August 1993 and from 25 July to 10 August 1994. Ears were harvested from 20 plants from the middle two rows of each experimental unit. The weight of ears with husk leaves, number of marketable ears, and number of ears with butt blanking were recorded. Within hybrids, ear weight was converted to a percentage of the mean of noninoculated control treatments.

Data were analyzed by analysis of variance (ANOVA). Noninoculated control treatments were excluded from ANOVA when the dependent variable did not vary (i.e., incidence and percent ear weight). Main effects of hybrids and viral treatments were compared by Waller-Duncan Bayesian least significant values when the hybrid by treatment interaction was not significant. Percent ear weight was plotted on incidence measured at the beginning of harvest and analyzed by ordinary least squares regressions. The increase in the percentage of ears with butt blanking from that in noninoculated control treatments also was plotted on MDM incidence and was analyzed by regression.

\section{RESULTS}

Symptomatic plants were not observed in noninoculated plots. In 1993, mean incidence of symptomatic plants for the 20 hybrids ranged from 0 to $68 \%, 4$ to $79 \%$, and 4 to $100 \%$ for the 22 June and 2 and 28 July ratings, respectively. In 1994, mean incidence for the 18 hybrids ranged from 4 to $92 \%$ and 1 to $100 \%$ for the 1 and 21 July ratings, respectively. The main effects of hybrids and viral treatments and the interaction of hybrids and treatments were sig- nificant in the ANOVAs of incidence measured at the beginning of the harvest during both years.

Incidence of systemic symptomatic plants differed among hybrids inoculated with MDMV-A or SCMV-MB (Tables 1 and 2). In 1993, incidence for all three viral treatments was less than $32 \%$ for seven hybrids: BiGuard, Dallas, Enforcer, GH2757, HMX 9352, Silverette, and Topacio (Table 1). For Esteem, GH 1209, Sundial, Terminator, and WH 3443, incidence was greater for plants inoculated with SCMV-MB than for plants inoculated with MDMV-A. Incidence of sectoring among symptomatic plants was $11 \%$ for GH 1759 and less than 5\% for all other hybrids (Table 1).

In 1994, incidence was less than $8 \%$ for BiGuard, Dallas, and Topacio inoculated with any of the three viral treatments (Table 2). Incidence was between 6 and $26 \%$ for all treatments of Enforcer, GH 1209, GH 2757, HMX 0381, and Sundial. Incidence was less than $35 \%$ when Elite, Esteem, HMX 9350, Sundance, and Terminator were inoculated with MDMV-A but more than 50\% when these hybrids were inoculated with SCMV-MB or MDMV-A/SCMV-MB. Incidence ranged from 77 to $100 \%$ for the susceptible checks: Crisp n Sweet 710-A, Excellency, and Green Giant Code 30. Elite, Esteem, Green Giant Code 29, Green Giant Code 30, HMX 9350, More, Sundance, and Terminator had lower incidences when inoculated with MDMV-A than when inocu-

Table 1. Incidence of maize dwarf mosaic (MDM) and sectoring among symptomatic plants of 20 sweet corn hybrids inoculated in 1993 with maize dwarf mosaic virus (MDMV-A) and/or sugarcane mosaic virus (SCMV-MB)

\begin{tabular}{|c|c|c|c|c|c|c|c|}
\hline \multirow[b]{2}{*}{ Hybrid } & \multirow[b]{2}{*}{$\begin{array}{l}\text { Endo- } \\
\text { sperm }\end{array}$} & \multirow[b]{2}{*}{$\begin{array}{c}\text { Kernel } \\
\text { color }^{\mathrm{a}}\end{array}$} & \multicolumn{4}{|c|}{ Incidence $^{\mathrm{b}}$ of $\mathrm{MDM}$ in treatments } & \multirow[b]{2}{*}{$\begin{array}{c}\text { Sectoring } \\
(\%)\end{array}$} \\
\hline & & & $\begin{array}{c}\text { MDMV-A } \\
(\%)\end{array}$ & $\begin{array}{c}\text { SCMV-MB } \\
(\%)\end{array}$ & $\begin{array}{c}\text { MDMV-A/ } \\
\text { SCMV-MB }(\%)\end{array}$ & $\begin{array}{l}\bar{X}^{\mathrm{c}} \\
(\%)\end{array}$ & \\
\hline BiGuard & $\mathrm{su}$ & B & 0 & 8 & 11 & 6 & 2 \\
\hline Dallas & su & $\mathrm{Y}$ & 1 & 12 & 4 & 6 & 0 \\
\hline Eliminator & su & Y & 17 & 43 & 15 & 28 & 1 \\
\hline Elite & se & $\mathrm{Y}$ & 68 & 76 & 68 & 70 & 4 \\
\hline Enforcer & su & Y & 8 & 30 & 28 & 22 & 1 \\
\hline Esteem & su & Y & 14 & 70 & 27 & 37 & 1 \\
\hline GH 1209 & $\mathrm{su}$ & Y & 13 & 58 & 23 & 31 & 11 \\
\hline GH 1759 & $\mathrm{su}$ & Y & 47 & 51 & 41 & 46 & 0 \\
\hline GH 2535 & $\mathrm{su}$ & $\mathrm{Y}$ & 9 & 38 & 33 & 24 & 3 \\
\hline GH 2681 & se & Y & 56 & 57 & 40 & 51 & 0 \\
\hline GH 2757 & se & $Y$ & 4 & 19 & 15 & 13 & 2 \\
\hline HMX 9352 & $\mathrm{sh}_{2}$ & $\mathrm{Y}$ & 8 & 0 & 3 & 4 & 0 \\
\hline HMX 9373 & su & $\mathrm{Y}$ & $\ldots$ & 100 & 100 & 100 & 0 \\
\hline More & su & Y & 70 & 98 & 97 & 88 & 1 \\
\hline Silverette & su & W & 24 & 29 & 13 & 22 & 3 \\
\hline Sundance & su & $\mathrm{Y}$ & 51 & 100 & 96 & 83 & 0 \\
\hline Sundial & se & $\mathrm{Y}$ & 5 & 38 & 2 & 15 & 1 \\
\hline Terminator & se & Y & 19 & 65 & 20 & 30 & 1 \\
\hline Topacio & se & $\mathrm{Y}$ & 4 & 18 & 9 & 10 & 0 \\
\hline WH 3443 & su & W & 9 & 40 & 3 & 19 & 1 \\
\hline $\bar{x}^{e}$ & & & 28 & 46 & 36 & & \\
\hline BLSD $^{f}$ & & & & 32 & & & \\
\hline
\end{tabular}

${ }^{\mathrm{a}} \mathrm{B}=$ bicolor, $\mathrm{Y}=$ yellow, and $\mathrm{W}=$ white.

b (Symptomatic plants/total plants) $\times 100$, rated 28 July 1993 .

c Means of hybrids.

${ }^{\mathrm{d}}$ Percentage of symptomatic plants sectoring (i.e., distinct bands of asymptomatic and symptomatic tissue).

${ }^{\mathrm{e}}$ Means of viral treatments.

${ }^{\mathrm{f}}$ Bayesian least significant difference for comparisons of combinations of hybrids and viral treatments. 
lated with SCMV-MB. More than half of the symptomatic plants of BiGuard, Dallas, HMX 0381, and Sundial sectored (Table 2). Incidence of sectoring symptoms ranged from GH 2757, HMX 9350, and Terminator.

Weights of 20 ears with husk leaves ranged from 3.5 to $7.2 \mathrm{~kg}$ among the combination of 20 hybrids and four treatments in 1993 and from 3.9 to $7.2 \mathrm{~kg}$ among the 18 hybrids and four treatments in 1994 . Hybrid means ranged from 4.0 to $6.8 \mathrm{~kg}$ in 1993 and from 4.1 to 6.7 in 1994. centage of controls ranged from 84 to $109 \%$ in 1993 (Table 3). Viral treatment means of 97, 95, and 95\% for the MDMV-A, SCMV$\mathrm{MB}$, and MDMV-A/SCMV-MB treatments did not differ. In 1994, hybrid means for percent ear weight ranged from 84 to $105 \%$ (Table 4). Viral treatment means of 99, 96, and $93 \%$ for the MDMV-A, SCMV-MB, and MDMV-A/SCMV-MB treatments differed. The hybrid by treatment interaction was not significant in either year.

Yields (percent ear weight) of Esteem, HMX 9373, More, Sundance, and Sundial were reduced $8 \%$ or more by MDM in 1993 (Table 3). Yields of Dallas, Elite, and GH 2535 were reduced from 4 to $8 \%$ by MDM in 1993. In 1994, yields of Crisp n Sweet 710A, Excellency, Green Giant Code 30, More, and Sundance were reduced $10 \%$ or more due to MDM (Table 4). Yields of Esteem, GH 1209, and HMX 9350 were reduced from 5 to $10 \%$ by MDM. 10 to $50 \%$ for Elite, Enforcer, GH 1209,

Hybrid means for ear weight as a per-

Because the main effect of viral treatments and the hybrid by viral treatment interaction were not significant in the ANOVA of percent yield in 1993, hybrid means were used in the regression of percent yield (ear weight) on incidence (Fig. 1). The slope coefficient was -0.15 , and the coefficient of determination was 0.44. In 1994, when the main effect of viral treatments was significant, percent yield of each hybrid was regressed on incidence within each MDM treatment (Fig. 2). Slope coefficients were $-0.085,-0.14$, and -0.15 , and coefficients of determination were $0.29,0.62$, and 0.63 for the MDMV-A, SCMV-MB, and MDMVA/SCMV-MB treatments, respectively. The slope for the MDMV-A treatment differed from the SCMV-MB and MDMV-A/SCMVMB treatments. The slopes for the SCMV$\mathrm{MB}$ and MDMV-A/SCMV-MB treatments did not differ.

Butt blanking varied between years and hybrids. In 1993, the main effect of hybrids was significant, but treatment and the interaction term were not. In 1994, the main effect of hybrids and treatments and the interaction of hybrids and treatments were highly significant. Hybrid means for percentage of butt blanking in 1993 ranged from 7 to $61 \%$ (Table 3). In 1994, percentages of butt blanking ranged from 3 to $68 \%$ for combinations of hybrids and viral treatments. Treatment means in 1994 were 23, 26, 30, and 19\% for MDMV-A, SCMVMB, MDMV-A/SCMV-MB, and the noninoculated control.

Table 2. Incidence of maize dwarf mosaic (MDM) and sectoring among symptomatic plants of 18 sweet corn hybrids inoculated in 1994 with maize dwarf mosaic virus (MDMV-A) and/or sugarcane mosaic virus (SCMV-MB)

\begin{tabular}{|c|c|c|c|c|c|c|c|}
\hline \multirow[b]{2}{*}{ Hybrida $^{a}$} & \multirow[b]{2}{*}{$\begin{array}{l}\text { Endo- } \\
\text { sperm }\end{array}$} & \multirow[b]{2}{*}{$\begin{array}{l}\text { Kernel } \\
\text { color }^{b}\end{array}$} & \multicolumn{4}{|c|}{ Incidence $^{c}$ of MDM in treatments } & \multirow[b]{2}{*}{$\begin{array}{c}\text { Sectoring } \\
(\%)\end{array}$} \\
\hline & & & $\begin{array}{c}\text { MDMV-A } \\
(\%)\end{array}$ & $\begin{array}{c}\text { SCMV-MB } \\
(\%)\end{array}$ & $\begin{array}{c}\text { MDMV-A/ } \\
\text { SCMV-MB }(\%)\end{array}$ & $\begin{array}{l}\bar{X}^{d} \\
(\%)\end{array}$ & \\
\hline BiGuard & $\mathrm{su}$ & B & 1 & 6 & 6 & 4 & 50 \\
\hline $\mathrm{CnS} 710 \mathrm{~A}$ & $\mathrm{sh}_{2}$ & $\mathrm{Y}$ & 99 & 100 & 99 & 99 & 0 \\
\hline Dallas & $\mathrm{su}^{2}$ & $\mathrm{Y}$ & 1 & 5 & 8 & 5 & 82 \\
\hline Elite & se & $\mathrm{Y}$ & 32 & 73 & 74 & 60 & 24 \\
\hline Enforcer & $\mathrm{su}$ & Y & 9 & 16 & 25 & 17 & 19 \\
\hline Esteem & $\mathrm{su}$ & Y & 34 & 59 & 66 & 53 & 7 \\
\hline Excellency & su & $\mathrm{Y}$ & 100 & 100 & 100 & 100 & 0 \\
\hline GG Code 29 & su & Y & 61 & 87 & 92 & 80 & 1 \\
\hline GG Code 30 & $\mathrm{su}$ & $\mathrm{Y}$ & 77 & 99 & 100 & 92 & 0 \\
\hline GH 1209 & $\mathrm{su}$ & $\mathrm{Y}$ & 8 & 20 & 12 & 13 & 39 \\
\hline GH 2757 & se & $\mathrm{Y}$ & 10 & 19 & 26 & 18 & 48 \\
\hline HMX 0381 & $\mathrm{sh}_{2}$ & B & 14 & 25 & 19 & 19 & 55 \\
\hline HMX 9350 & $\mathrm{su}$ & Y & 22 & 56 & 62 & 47 & 13 \\
\hline More & $\mathrm{su}$ & $\mathrm{Y}$ & 61 & 87 & 96 & 93 & 0 \\
\hline Sundance & su & Y & 23 & 97 & 95 & 72 & 0 \\
\hline Sundial & se & $\mathrm{Y}$ & 6 & 18 & 11 & 11 & 85 \\
\hline Terminator & se & $\mathrm{Y}$ & 35 & 51 & 58 & 48 & 14 \\
\hline Topacio & su & Y & 0 & 2 & 1 & 1 & 0 \\
\hline $\bar{x}^{f}$ & & & 35 & 51 & 53 & & \\
\hline BLSD $^{g}$ & & & & 6 & & & \\
\hline
\end{tabular}

${ }^{\mathrm{a}} \mathrm{CnS}=$ Crisp n Sweet and GG - Green Giant.

${ }^{\mathrm{b}} \mathrm{B}=$ bicolor and $\mathrm{Y}=$ yellow.

c (Symptomatic plants/total plants $) \times 100$, rated 21 July 1994 .

d Means of hybrids.

e Percentage of symptomatic plants sectoring (i.e., distinct bands of asymptomatic and symptomatic tissue).

${ }^{\mathrm{f}}$ Means of viral treatments.

g Bayesian least significant difference for comparisons of combinations of hybrids and treatments.
In 1993, butt blanking was less than $10 \%$ for BiGuard and Terminator (Table 3). Butt blanking was between 13 and $18 \%$ for Eliminator, GH 1209, and Silverette. In 1994, butt blanking for many hybrids did not differ between viral treatments and the noninoculated treatment, including BiGuard, Dallas, and Terminator, for which butt blanking was less than 17\%, GH 1209, HMX 0381, and HMX 9350, for which butt blanking was from 12 to $36 \%$, and Enforcer, GH 2757, Sundial, and Topacio, for which butt blanking was from 23 to $45 \%$ (Table 4 ). For three hybrids, Crisp n Sweet 710A, More, and Sundance, the percentage of ears with butt blanking was higher for all three viral treatments than for the noninoculated control. For five hybrids, Elite, Esteem, Excellency, Green Giant Code 29, and Green Giant Code 30, the percentage of ears with butt blanking was greater for the SCMVMB/MDMV-A treatment than for the noninoculated treatment, but butt blanking did not differ between the MDMV-A and noninoculated control treatments (Table 4).

Incidence of MDM was more than $60 \%$ for 14 of 15 hybrid/viral treatments for which butt blanking was greater than the noninoculated control in 1994 (Tables 2 and 4) Similarly, of 21 hybrid/viral treatments with MDM incidence of $50 \%$ or more in 1994, 14 had butt blanking that was significantly greater than the noninoculated treatment.

Table 3. Weight of ears with husk leaves as a percentage of the noninoculated control and incidence of butt blanking for 20 sweet corn hybrids inoculated in 1993 with maize dwarf mosaic virus (MDMV-A) and/or sugarcane mosaic virus (SCMV-MB)

\begin{tabular}{lrc}
\hline Hybrid & $\begin{array}{c}\text { Ear } \\
\text { weight }^{\mathbf{a}} \\
(\boldsymbol{\%})\end{array}$ & $\begin{array}{c}\text { Butt } \\
\text { blanking } \\
(\boldsymbol{\%})\end{array}$ \\
\hline BiGuard & 97 & 7 \\
Dallas & 96 & 30 \\
Eliminator & 100 & 13 \\
Elite & 94 & 61 \\
Enforcer & 98 & 31 \\
Esteem & 87 & 32 \\
GH 1209 & 98 & 18 \\
GH 1759 & 99 & 28 \\
GH 2535 & 95 & 24 \\
GH 2681 & 100 & 29 \\
GH 2757 & 100 & 37 \\
HMX 9352 & 97 & 38 \\
HMX 9373 & 86 & 45 \\
More & 86 & 35 \\
Silverette & 102 & 16 \\
Sundance & 84 & 34 \\
Sundial & 92 & 37 \\
Terminator & 98 & 8 \\
Topacio & 102 & 36 \\
WH 3443 & 109 & 23 \\
BLSD & & 11 \\
- & 4 &
\end{tabular}

a Mean of three viral treatments (i.e., MDMVA, SCMV-MB, and combination of both) as a percentage of the noninoculated control for each hybrid.

b Percentage of ears with poor kernel fill at the basal portion of the ear.

c Bayesian least significant difference value $(k=$ 100) for comparisons of hybrid means. 
Thus, an increase in butt blanking from that which occurred in the noninoculated treatment was associated with a high incidence of MDM. In both years, there was a significant linear relationship between the increase in the percentage of ears with butt blanking (from that in the noninoculated control treatment) and incidence of MDM. Regression coefficients ranged from 0.13 to 0.27 , and coefficients of determination ranged from 0.38 to 0.85 .

\section{DISCUSSION}

Resistance to MDM in commercial sweet corn hybrids significantly lowered the incidence of symptomatic plants and reduced the adverse effects of MDM on yield, but it did not prevent all infections. None of the hybrids in this study were $100 \%$ asymptomatic when inoculated with MDMV-A and/ or SCMV-MB. Hybrids differed in the effectiveness of MDM resistance. Incidence of symptomatic plants was below $20 \%$ for all viral treatments (MDMV-A, SCMV-MB, and MDMV-A/SCMV-MB) in both years for four hybrids: BiGuard, Dallas, HMX 9352, and Topacio. These hybrids appeared to have greater resistance than the other hybrids evaluated in this study, based on a lower incidence of symptomatic plants. A second group of hybrids had moderate levels of resistance to MDM based on an incidence of symptomatic plants that was greater than the most resistant hybrids but lower than the susceptible hybrids. Incidence of symptomatic plants was $30 \%$ or less for Enforcer and GH 2757 in both trials, for Silverette in the 1993 trial, and for HMX 0381 in the 1994 trial. Some hybrids (i.e., Eliminator, Elite, Esteem, GH 1209, HMX 9350, Terminator, and WH 3443) appeared to have greater resistance to MDMV-A than to SCMV-MB, based on significant differences in incidence of symptoms when plants were inoculated with either of the two viruses.

Even though reactions to MDMV-A and SCMV-MB differed among the resistant sweet corn hybrids in this study, all of the resistant hybrids probably carry the $M d m-1$ gene, because widely used sources of resistance in sweet corn were derived from $\mathrm{Pa}$ 405 or B68. Differences among MDM-resistant sweet corn hybrids in our trial may be due to the specific source of resistance or whether both inbred parents contributed resistance genes to the $F_{1}$ hybrids.

Although the homozygous condition is not necessary for asymptomatic, resistant reactions in $F_{1}$ hybrids, as is evident in several studies in which $\mathrm{F}_{1}$ hybrids with $\mathrm{Pa} 405$ as a resistant parent were asymptomatic $(15,20,23)$, it is conceivable that two resistant inbreds may produce an $\mathrm{F}_{1}$ hybrid with higher levels of MDM resistance, because each resistant inbred may carry different modifiers of the $M d m 1$ gene. Assuming that $\mathrm{Pa} 405$ has the full compliment of modifiers (because $F_{1}$ hybrids with this line usually are asymptomatic), the lack of modifiers of $M d m 1$ in some MDM-resistant sweet corn inbreds may limit the degree to which MDM-resistance restricts viral movement, especially when inoculum is introduced in close proximity to meristematic tissues. Thus, incidence of symptomatic plants in hybrids produced from these resistant inbreds is less than that for susceptible hybrids but greater than other MDM-resistant materials. Similarly, reactions to MDMVA and SCMV-MB may be affected by modifiers of $M d m-1$.

Our results agree with those of Scheifele and Wernham (24), who found that hybrids can differ in reactions to MDMV-A and SCMV-MB. Incidence differed significantly between MDMV-A and SCMV-MB for 5 and 11 hybrids in 1993 and 1994, respectively. In each case, incidence was lower for plants inoculated with MDMV-A. In another study (9), we observed a higher incidence of MDM due to MDMV-A than SCMV-MB in backcrosses of sweet corn inbreds when $\mathrm{Pa} 405$ was the source of resistance. Another explanation for these results may be that our isolates of SCMV-

Table 4. Weight of maize ears with husk leaves as a percentage of the noninoculated control and incidence of butt blanking for 18 sweet corn hybrids inoculated in 1994 with maize dwarf mosaic virus (MDMV-A) and/or sugarcane mosaic virus (SCMV-MB)

\begin{tabular}{|c|c|c|c|c|c|}
\hline \multirow[b]{2}{*}{ Hybrid } & \multirow[b]{2}{*}{$\begin{array}{c}\text { Ear } \\
\text { weight }^{\mathrm{a}}(\%)\end{array}$} & \multicolumn{4}{|c|}{ Butt blanking $^{b}$ in MDM treatments } \\
\hline & & $\begin{array}{c}\text { MDMV-A } \\
(\%)\end{array}$ & $\begin{array}{c}\text { SCMV-MB } \\
(\%)\end{array}$ & $\begin{array}{c}\text { MDMV-A/ } \\
\text { SCMV-MB }(\%)\end{array}$ & $\operatorname{CK}^{\mathrm{c}}(\%)$ \\
\hline BiGuard & 103 & 3 & 4 & 7 & 8 \\
\hline Crisp n Sweet 710A & 88 & 41 & 39 & 51 & 15 \\
\hline Dallas & 105 & 17 & 9 & 10 & 17 \\
\hline Elite & 96 & 49 & 66 & 68 & 39 \\
\hline Enforcer & 101 & 29 & 27 & 37 & 39 \\
\hline Esteem & 93 & 15 & 17 & 29 & 11 \\
\hline Excellency & 90 & 11 & 21 & 31 & 6 \\
\hline Green Giant Code 29 & 100 & 23 & 30 & 36 & 14 \\
\hline Green Giant Code 30 & 89 & 5 & 14 & 23 & 3 \\
\hline GH 1209 & 93 & 12 & 15 & 18 & 22 \\
\hline GH 2757 & 99 & 30 & 30 & 36 & 34 \\
\hline HMX 0381 & 96 & 17 & 13 & 17 & 22 \\
\hline HMX 9350 & 94 & 24 & 30 & 19 & 25 \\
\hline More & 89 & 33 & 36 & 37 & 10 \\
\hline Sundance & 84 & 25 & 36 & 28 & 7 \\
\hline Sundial & 100 & 30 & 23 & 36 & 29 \\
\hline Terminator & 97 & 5 & 13 & 14 & 2 \\
\hline Topacio & 102 & 45 & 39 & 43 & 35 \\
\hline BLSD & $5^{\mathrm{d}}$ & & $16^{\mathrm{e}}$ & & \\
\hline
\end{tabular}

a Mean of three viral treatments (i.e., MDMV-A, SCMV-MB, and combination of both) as a percentage of the noninoculated control for each hybrid.

$\mathrm{b}$ Percentage of ears with poor kernel fill at the basal portion of the ear.

c Noninoculated control plot.

d Bayesian least significant difference (BLSD) value $(k=100)$ for comparisons of hybrid means.

e BLSD for comparison of hybrid-treatment combinations.

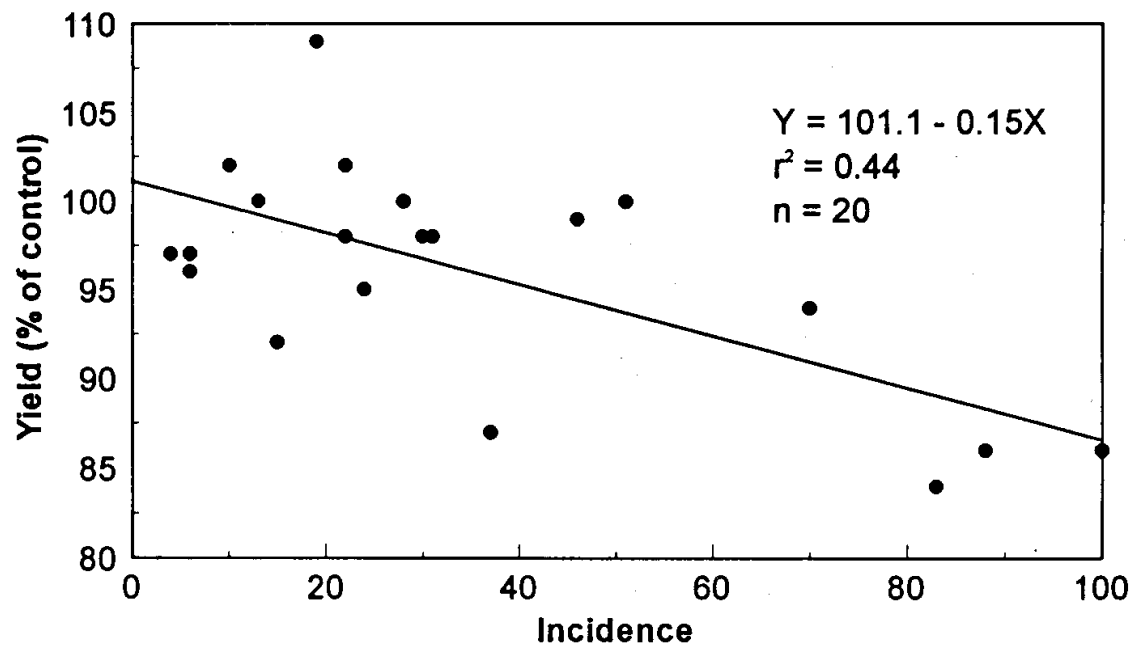

Fig. 1. Yield (ear weight) as a percentage of noninoculated controls of 20 sweet corn hybrids inoculated with maize dwarf mosaic virus (MDMV-A), sugarcane mosaic virus (SCMV-MB), or MDMV-A/ SCMV-MB regressed on incidence of maize dwarf mosaic-infected plants measured at the beginning of the harvest (28 July 1993). Each data point represents a hybrid mean of three replicates of three viral treatments (MDMV-A, SCMV-MB, and MDMV-A/SCMV-MB). 


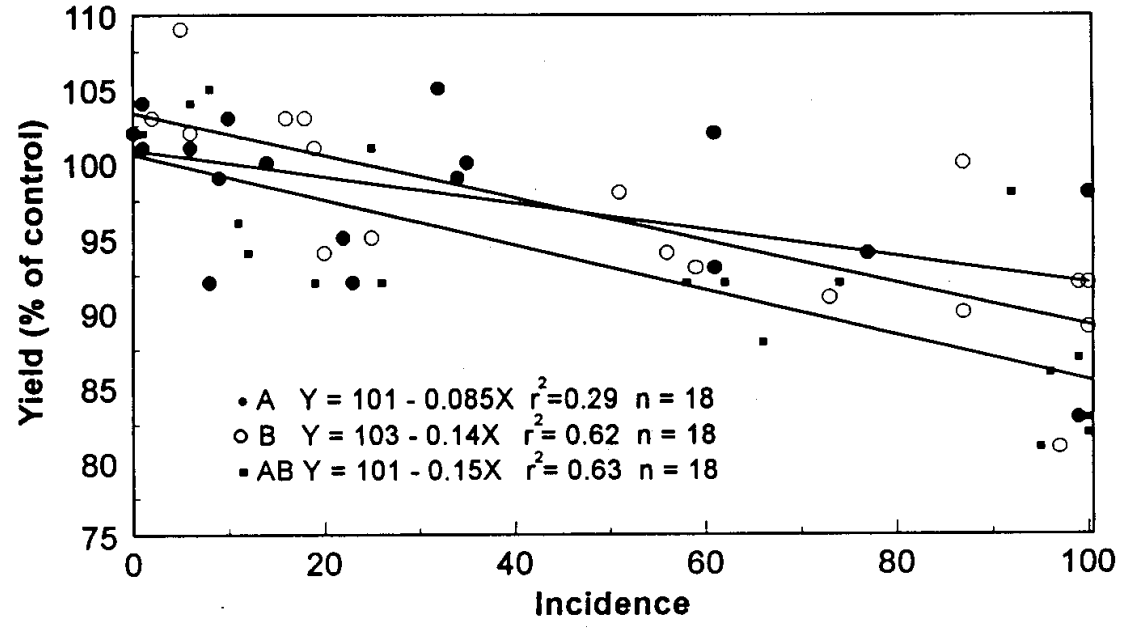

Fig. 2. Yield (ear weight) as a percentage of noninoculated controls of 18 sweet corn hybrids inoculated with maize dwarf mosaic virus (MDMV-A), sugarcane mosaic virus (SCMV-MB), or MDMVA/SCMV-MB regressed on incidence of maize dwarf mosaic-infected plants measured at the beginning of the harvest (21 July 1994). Each data point represents the mean of five replicates of three viral treatments (MDMV-A, SCMV-MB, and MDMV-A/SCMV-MB).

MB had a greater ability to cause symptoms than did our isolates of MDMV-A.

Plants displaying sectoring symptoms were more prevalent in 1994 than in 1993. In 1994, sectoring symptoms were observed in half or more of the symptomatic plants of four hybrids: BiGuard, Dallas, GH 2757, and HMX 0381. Jones and Tolin (7) suggested that sectoring is an expression of resistance, so it is not surprising that these symptoms were most prevalent in hybrids for which incidence of symptomatic plants was relatively low. Sectoring is a categorical measurement of response to viral infection. We did not attempt to make a numerical measurement (e.g., severity) of MDM symptoms, because previous research has indicated a lack of association between symptom severity and titer (21).

Yields of hybrids with some resistance to MDM were not affected greatly by MDM. Yields were lowered by 10 to $20 \%$ compared to the noninoculated control plots for only four hybrids in 1993 and 1994. Slope coefficients of -0.15 in 1993 and from 0.085 to -0.15 in 1994 , which correspond to an approximately $15 \%$ yield reduction when MDM infection was $100 \%$, were similar to the lower end of the range of yield losses observed in previous studies $(5,17$, 21). None of the hybrids with higher levels of MDM resistance had more than $18 \%$ incidence, and yields were not affected for these hybrids. Butt blanking also was lower for hybrids with low incidence of symptomatic plants. Although slope coefficients from regressions of butt blanking on incidence were slightly more negative than those from regressions of percent yield (ear weight) and incidence, the effects of MDM on ear weight and butt blanking were similar to those observed previously (21).

In this study, plants were inoculated two to three times beginning at the three-leaf stage, which may be comparable to lateplanted sweet corn under moderate pressure from viruliferous aphids. If populations of viruliferous aphids are as low as usual in most years in the major sweet cornproducing regions of the Midwest, yield of currently available MDM-resistant hybrids probably will not be adversely affected by this disease, although some symptomatic plants may be seen. In areas with higher populations of viruliferous aphids and where johnsongrass (Sorghum halapense) occurs (i.e., the Ohio River Valley), incidence of MDM on resistant sweet corn may be higher than desired, but hybrids with resistance should perform better than susceptible hybrids.

\section{ACKNOWLEDGMENTS}

We thank J. Gantz, C. Nankam, L. Adams, and J. Manuel for technical assistance.

\section{LITERATURE CITED}

1. Anzola, D., Romaine, C. P., Gregory, L. V., and Ayers, J. E. 1982. Disease response of sweet corn hybrids derived from dent corn resistant to maize dwarf mosaic virus. Phytopathology 72:601-604.

2. Bar-Zur, A., and Salomon, R. 1995. Partial resistance of sugary enhancer sweet corn genotypes to two isolates of the sugarcane mosaic subgroup of potyviruses. Plant Dis. 79:243246.

3. Dollinger, E. J., Findley, W. R., and Williams, L. E. 1970. Resistance inheritance to maize dwarf mosaic virus in maize (Zea mays L.). Crop Sci. 10:412-415.

4. Findley, W. R., Dollinger, E. J., Louie, R., and Knoke, J. K. 1973. Locating genes for maize dwarf mosaic resistance by means of chromosomal translocations in corn. Crop Sci. 13: 608-611.

5. Gregory, L.V., and Ayers, J. E. 1982. Effect of inoculation with maize dwarf mosaic virus at several growth stages on yield of sweet corn. Plant Dis. 66:801-804.
6. Janson, B. F., and Ellett, C. W. 1963. A new corn disease in Ohio. Plant Dis. Rep. 47:1107-1108.

7. Jones, R. K., and Tolin, S. A. 1972. Concentration of maize dwarf mosaic virus in susceptible and resistant corn hybrids. Phytopathology 62:640-644.

8. Juvik, J. A., and D'Arcy, C. J. 1988. Sugary (su) and sugary enhancer (se) sweet corn inbreds with resistance to maize dwarf mosaic virus. HortScience 23:412-413.

9. Kerns, M. R. 1996. Resistance to maize dwarf mosaic virus in sweet corn. M.Sc. thesis. University of Illinois, Urbana-Champaign.

10. Kuhn, C. W., and Smith, T. H. 1977. Effectiveness of a disease index system in evaluating corn for resistance to maize dwarf mosaic virus. Phytopathology 67:288-291.

11. Law, M. D., Moyer, J. W., and Payner, G. A. 1989. Effect of host resistance on pathogenesis of maize dwarf mosaic virus. Phytopathology 79:757-761.

12. Lei, J. D., and Agrios, G. N. 1986. Mechanisms of resistance in corn to maize dwarf mosaic virus. Phytopathology 76:1034-1040.

13. Loesch, P. J., and Zuber, M. S. 1967. An inheritance study of resistance to maize dwarf mosaic virus in corn (Zea mays L.). Agron. J. 59:423-426.

14. Louie, R., Findley, W. R., Knoke, J. K., and McMullen, M. D. 1991. Genetic basis of resistance in maize to five maize dwarf mosaic virus strains. Crop Sci. 31:14-18.

15. McMullen, M. D., and Louie, R. 1993. The genetic and biological bases of resistance in maize to MDMV and WSMV. Pages 62-73 in: 29th Ann. Corn Breed. School. University of Illinois, Champaign.

16. Mikel, M. A., D’Arcy, C. J., Carey, E. E., and Juvik, J. A. 1983. Sugary (su) sweet corn germplasm with resistance to maize dwarf mosaic virus. HortScience 18:964-965.

17. Mikel, M. A., D'Arcy, C. J., Rhodes, A. M., and Ford, R. E. 1981. Yield response of sweet corn to maize dwarf mosaic virus. Plant Dis. 65:900-901.

18. Mikel, M. A., D’Arcy, C. J., Rhodes, A. M., and Ford, R. E. 1981. Yield loss in sweet corn correlated with time of inoculation with maize dwarf mosaic virus. Plant Dis. 65:902-904.

19. Mikel, M. A., D’Arcy, C. J., Rhodes, A. M. and Ford, R. E. 1982. Effect of maize dwarf mosaic virus infection on sweet corn pollen and silk. Phytopathology 72:428-431.

20. Mikel, M. A., D’Arcy, C. J., Rhodes, A. M., and Ford, R. E. 1984. Genetics of resistance of two dent corn inbreds to maize dwarf mosaic virus and transfer of resistance into sweet corn. Phytopathology 74:467-473.

21. Pataky, J. K., Murphy, J. F., and D'Arcy, C. J. 1990. Resistance to maize dwarf mosaic virus, severity of symptoms, titer of virus, and yield of sweet corn. Plant Dis. 74:359-364.

22. Roane, C. W., Tolin, S. A., and Genter, C. F 1983. Inheritance of resistance to maize dwarf mosaic virus in maize inbred line Oh7B. Phytopathology 73:845-850.

23. Rosenkranz, E. 1987. New hosts and taxonomic analysis of the Mississippi native species tested for reaction to maize dwarf mosaic and sugarcane mosaic viruses. Phytopathology 77 598-607.

24. Scheifele, G. L., and Wernham, C. C. 1969. Further evidence supporting the hypothesis that two genetic systems control disease reaction to maize dwarf mosaic virus strain A and strain B. Plant Dis. Rep. 53:150-151.

25. Scott, G. E., and Rosenkranz, E. 1987. Variable reaction within corn inbreds to maize dwarf mosaic virus not genetically controlled. Crop Sci. 27:78-79. 